\title{
DOLOČANJE KRATKOROČNIH SPREMEMB NA KLIFU MED FIESO IN PACUGOM S PODATKI LETALSKEGA LIDARJA
}

\author{
dr. Nataša Kolega*, Patricija Prelc**, mag. \\ *Harpha sea, d. o. o., Čevljarska 8, SI-6000 Koper \\ in
}

Fakulteta za humanistične študije, Univerza na Primorskem

Titov trg 5, SI-6000 Koper

**Kolodvorska cesta I4a, SI-6257 Pivka

e-pošta: natasa.kolega@fhs.upr.si,prelc.patricija@gmail.com

Izvirni znanstveni članek

COBISS 1.01

DOI: $10.4312 /$ dela.45.2.31-48

\section{Izvleček}

Prispevek obravnava problematiko določanja kratkoročnih sprememb na flišnih klifih na slovenski obali s pomočjo dveh nizov podatkov letalskega lidarskega snemanja (z vmesnim razmikom treh let). Metoda se še razvija in se običajno uporablja v kombinaciji s terestričnim lidarjem. Na klifu med Fieso in Pacugom smo izvedli eksperimentalni poskus določanja kratkoročnih sprememb: največji delež razlik se je zgodil na steni klifa in abrazijski polici ter na osrednjem delu klifa, iz česar sklepamo, da je to najaktivnejši del klifa. Raziskava je pokazala, da je uporaba letalskih lidarskih posnetkov kljub določenim pomanjkljivostim lahko zelo uporaben pripomoček.

Ključne besede: flišni klifi, recentno spreminjanje obale, lidarsko snemanje, oblak točk, klif med Fieso in Pacugom, slovenska obala

\section{DETERMINING SHORT-TERM CHANGES ON CLIFF BETWEEN FIESA AND PACUG WITH AIRBORN LIDAR DATA}

\begin{abstract}
The paper deals with the problem of determining short-term changes in the flysch cliffs on Slovenian coast using two datasets of airborn lidar scannings, with an interval of three years. Method has still been developing, it is usually combined primarily with terrestrial lidar. In the case study area of the cliff between Fiesa and Pacug (Slovenia) we undertook experimental test: most of the changes occurred on the wall of the cliff and on abrasion platform, on the central part of the cliff. We can conclude that this is the most active part of the cliff. Despite several deficiencies, the method has proven to be useful and relatively reliable.
\end{abstract}

Key words: flysch cliffs, recent coast changes, lidar scanning, point cloud, cliff between Fiesa and Pacug, Slovenian coast 


\section{UVOD}

Na slovenski obali flišni klifi predstavljajo 60 \% obale (Orožen Adamič, 1990). Kljub tako močni zastopanosti pa je raziskav kratkoročnega spreminjanja flišnih klifov na slovenski obali razmeroma malo. Izpostaviti velja predvsem raziskave Žumra (1990), Radinje (1973), Gamsa (1970) in Furlanija (2007, 2011a, 2011b). Članek obravnava za slovenske razmere eksperimentalni poskus določanja kratkoročnih sprememb na flišnem klifu s podatki letalskega lidarja. Za območje raziskave je bil izbran klif med Fieso in Pacugom, saj je na njem prisotnih relativno malo človekovih posegov.

Za del obale med Fieso in Pacugom so na voljo podatki dveh lidarskih snemanj, tj. iz let 2007 in 2010. S primerjavo smo želeli ugotoviti, če je mogoče iz dveh nizov lidarskih podatkov, posnetih v razmiku treh let, razbrati kakršne koli spremembe na klifih, ali je natančnost podatkov dovolj velika glede na velikost sprememb na klifih ter kakšni metodološki pristopi so za to najprimernejši.

\section{I.I Preučevanje flišnih klifov na slovenski obali}

Fliš na slovenski obali se je začel usedati v zgornjem luteciju na robovih tektonsko aktivne Jadransko-dinarske karbonatne platforme. Podgorski bazen (nastal ob Dinarski orogenezi) se je polnil z eocenskimi terigenimi turbiditi, ki so nastali z erozijo dvigajoče se gorske verige (Placer, 2008; Furlani in sod., 2011a, 2011b), v manjši meri pa z odlaganjem globokomorskih sedimentov (Peckmann, 1995). Hitrost sedimentacije fliša na opazovanem območju je brez upoštevanja kompaktizacije znašala $1 \mathrm{~m} /$ leto (Peckmann, 1995; Šegina, 2012). Najprej se je odložil grobozrnati material, peščenjaki, nato pa bolj drobnozrnato gradivo, laporovec. Obe plasti sta nastali ob istem dogodku in predstavljata eno flišno sekvenco (Zorn, 2008). Fliš v hidrogeološkem smislu predstavlja slabo do srednje prepustne kamnine. Prav zaradi te lastnosti opažamo površinske erozijske oblike, kot so žlebiči in erozijski jarki (Šegina, 2012).

Morski klif je po opredelitvah strmo skalnato, lahko skoraj navpično ali celo previsno pobočje, ki se dviga nad morsko gladino. Nastane zaradi dolgotrajnega delovanja morskih ali jezerskih valov. Spodmoli nastajajo na bregovih, ko se na abrazijski polici valovi lomijo in tolčejo ob njo. Za nastanek klifa mora biti kamnina dovolj kompaktna. $\mathrm{Ob}$ pomoči erozije se v spodnjem delu previsne stene klif umika v notranjost kopnega, zaradi česar se manjša, abrazijska polica pod njim pa se tako povečuje in morje daljša (Kladnik, 2001, str. 628). Na umikanje klifa vpliva veliko različnih elementov: sedanja in pretekla klima, spremembe v relativni višini morske gladine, struktura in litografija kamnine ter tudi morfologija zaledja (Schwartz, 2005).

Leta 2012 je bila narejena raziskava dejavnikov umikanja klifov na slovenski obali (Šegina, Komac, Zorn, 2012): študija je zajemala 4,13 km obalne linije med rtom Kane in Strunjanom. Na osnovi literature in terenskega dela so opredelili deset dejavnikov, ki vplivajo na hitrost erozijskih procesov in s tem na hitrost umikanja klifov: debelina plasti peščenjaka, razmerje med laporovcem in peščenjakom v flišu, prisotnost apnenca ali peščenih karbonatnih turbiditov, smer plasti in naklon, strukturne deformacije (gube in prelomi), indeks geološke moči, strmina pobočij, prisotnost vode v razpokah, rastlinstvo in stopnja morske 
erozije. Ugotovili so, da manjša debelina peščenjakovih plasti pripomore $\mathrm{k}$ hitrejšemu umikanju obale v notranjost. Tanjše plasti so bolj izpostavljene vremenskim vplivom. Na predelih z debelejšo plastjo peščenjaka so prisotni erozijski jarki in usadi, medtem ko so na predelih s tanjšimi plastmi pogostejši podori. Prisotnost apnenčastega turbidita ni povezana s prisotnostjo usadov, jarkov in erozijskih žlebičev (Šegina, Komac, Zorn, 2012). Ocen o hitrosti odmikanja klifov na raznih mestih Koprskega primorja imamo več, gibljejo se od nekaj milimetrov do $2 \mathrm{~cm}$ letno, na posameznih delih pa tudi več (Žumer, 1990; Radinja, 1973).

Vegetacija zraste predvsem na območjih, ki so manj aktivna. Zgornji deli klifov so skoraj popolnoma goli. Tukaj vegetacija ne igra opazne vloge pri utrjevanju pobočja in preprečevanju odnašanja gradiva, vendar pa je njena prisotnost pomembna $\mathrm{v}$ spodnjih delih pobočja, kjer je zrasla na akumuliranem gradivu. Podori se večinoma sprožijo na odsekih brez vegetacije predvsem zaradi velikih naklonov (Šegina, Komac, Zorn, 2012).

Stopnja morske erozije je neposredno odvisna od energije valovanja, torej višine valov. V predelih, kjer ni neposrednega stika klifa z morsko vodo, prihaja do erozijskih žlebičev in jarkov, saj ti za svoj nastanek potrebujejo golo skalo. Podori se pojavijo na vseh vrstah stika (stik klifa z morjem ali brez njega). Do pojava usadov prihaja, kjer ni neposrednega stika klifa z morjem (Šegina, Komac, Zorn, 2012).

Furlani in sod. (2011a) je karakteriziral geomehanske značilnosti in kakovosti skalnih gmot na klifu na Debelem rtiču. Analizirali so dovzetnost za podore na stenah klifov. Spremembe pečin se pojavljajo $\mathrm{v}$ točkah, kjer so ugotovili slabo ali zelo slabo kakovost skalnih gmot. Najdovzetnejša kamnina za umikanje klifa je laporovec, saj ga bližina morja najbolj prizadene. Kjer peščenjak prevladuje v smeri vertikalne plastovitosti, prihaja do območij podorov. Skale ob vznožju pečine delujejo hkrati kot ovira morskim procesom in kot abrazija, ki deluje na dnu pobočja. Raziskava je pokazala, da so ob mirnih vremenskih obdobjih spremembe zelo majhne, večje spremembe na čelu klifa se pojavijo ob močnejših nevihtah. Analiza je potrdila, da je dosledno fotografiranje lahko podlaga za nadaljnje analize tako geomorfnih procesov kot določanja stopnje umikanja klifa (Furlani in sod., 2011a).

\section{I.2 Nekatere značilnosti klifa med Fieso in Pacugom}

Klif med Fieso in Pacugom je večinoma v višinskem razredu 0-10 m (slika 1). Kar $36,21 \%$ celotne površine spada v ta razred. Drugi najbolj zastopani višinski razred spada $\mathrm{v}$ kategorijo $40-50 \mathrm{~m}$ nadmorske višine (12,33 \%). Takoj za njim sta dva razreda: 30-40 m nadmorske višine z $11,67 \%$ površine in 50-60 m nadmorske višine z $11,12 \%$ površja. Abrazijska polica je v višinskem razredu $0-10 \mathrm{~m}$. Stena klifa je v razredu 10-20 m nadmorske višine, zgornji rob klifa pa na nekaterih mestih doseže tudi razred 30-40 m nadmorske višine. Zaledje klifa je grič, kjer je najvišja točka $82 \mathrm{~m}$ nadmorske višine.

Nakloni klifa so zelo pomembni zaradi erodiranja klifa. Večji je naklon, več gradiva erodira s stene klifa. Obravnavano območje ima največji odstotek površine v naklonih $40-50^{\circ}$, in sicer kar $20,15 \%$ površja. Flišna klifna stena spada v naklonski razred $60-90^{\circ}$ $\left(16,95 \%\right.$ ali $5901 \mathrm{~m}^{2}$ površja). Abrazijska polica spada v razred $0-30^{\circ}$, kar dopušča morju dostop visoko nanjo. Kar $11.614 \mathrm{~m}^{2}$ površine obravnavanega območja je abrazijska polica, ki obsega $33,35 \%$ celotnega klifa. V razredu $20-30^{\circ}$ je $9,57 \%$ površine, v razredu 
Slika 1: Nadmorske višine preučevanega območja.

Figure 1: Case study area-altitude categories.

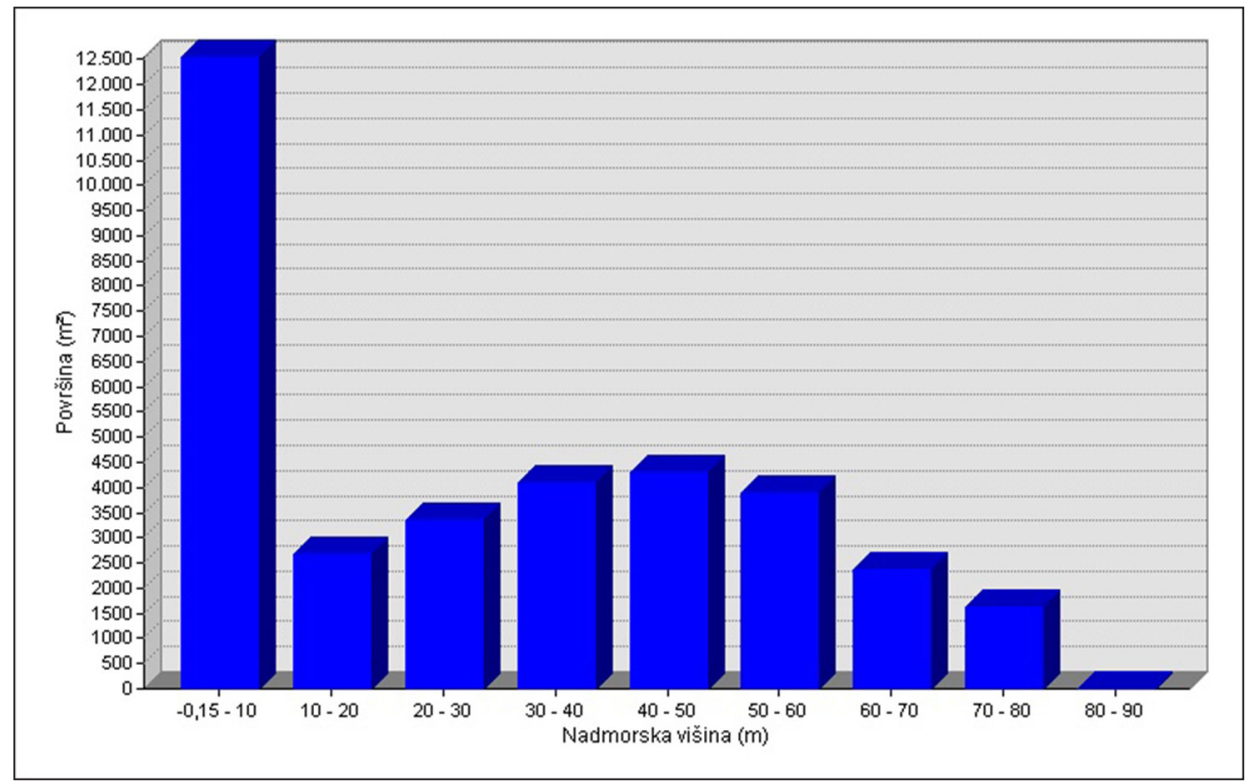

Slika 2: Nakloni preučevanega območja.

Figure 2: Case study area - slopes inclination.

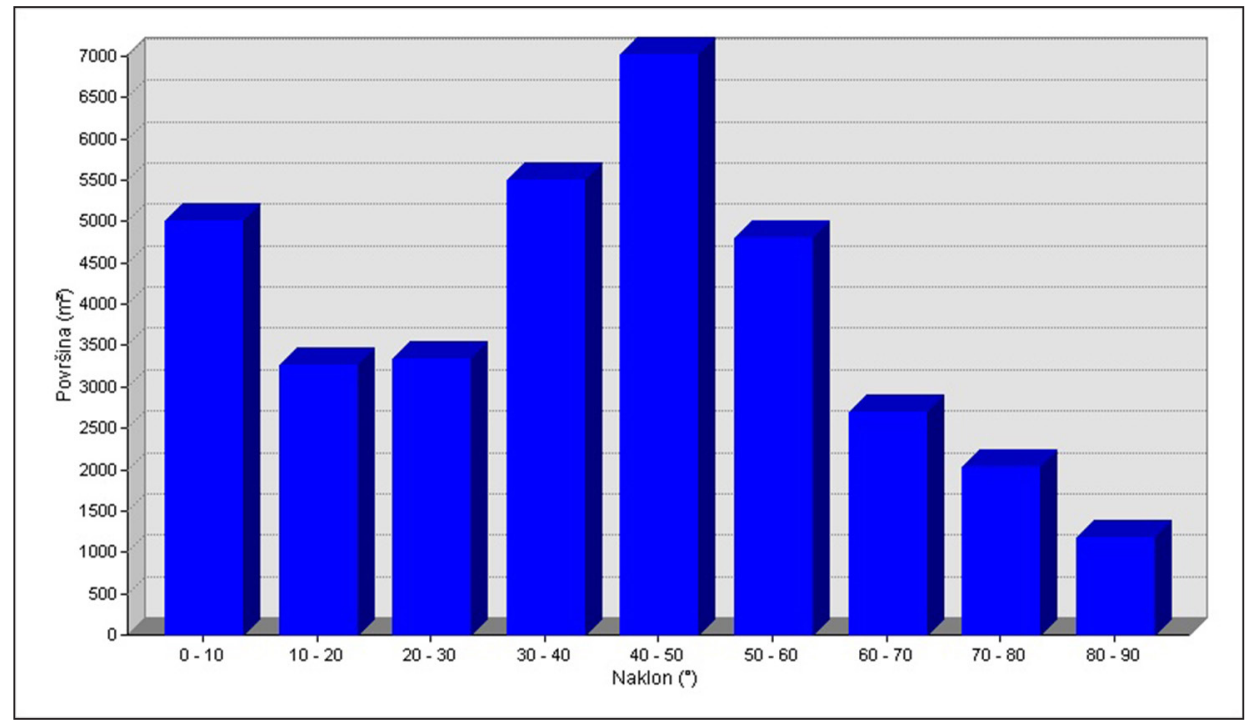


$30-40^{\circ}$ pa $15,77 \%$. Najmanj površine spada v razred naklona $80-90^{\circ}$, in sicer $1182 \mathrm{~m}^{2}$, kar obsega 3,39 \% klifa. Melišča pod klifom dosegajo naklone tudi do $60^{\circ}$. Stena klifa je v razredu večjih naklonov, doseže pa tudi vrednost $89^{\circ}$. Zaledje klifa je grič, kjer se nakloni zelo spreminjajo (slika 2).

Obravnavani klif je na nekaterih delih visok tudi več kot $30 \mathrm{~m}$. Območje je zaščiteno v okviru Nature 2000 (Vlada RS, 2004). Skupna dolžina obravnavanega klifa je približno $550 \mathrm{~m}$. Klif je obrnjen v smeri vzhod-zahod. Na vzhodni strani se nahaja kraj Pacug z letoviščem za otroke, na zahodni pa turistični kraj Fiesa.

\section{METODE DELA}

Lidarski snemanji je izvedlo podjetje Flycom, d. o. o. za podjetje Harpha sea, d. o. o. iz Kopra (2007a, 2007b, 2010a, 2010b). Podatkov lidarskega snemanja, ki ga je izvajala Geodetska uprava Republike Slovenije v okviru snemanja ozemlja celotne države, nismo uporabili, saj je bilo preučevano območje ravno tako posneto leta 2010, natančnost in gostota podatkov pa sta manjši od natančnosti podatkov, uporabljenih v tem prispevku.

V raziskavi smo uporabili surove lidarske podatke $v$ obliki oblaka točk. Ker je bilo za našo raziskavo pomembno zgolj spreminjanje klifa, torej tal, smo oblak točk klasificirali zgolj v dva razreda: tla ter vse ostale točke. Ker je določanje talnih točk na pobočju klifa zaradi prepletanja kamninske osnove in vegetacije ter spreminjanja naklona in izoblikovanosti površja zapleten postopek, smo mu posvetili precej pozornosti. Klasifikacije tal na območju klifa ni mogoče izvesti z že pripravljenimi algoritmi, saj so ti prilagojeni drugačnim (enostavnejšim) tipom površja. Klasifikacija tal je zato obsegala v veliki meri ročno klasificiranje s pomočjo ozkih prečnih prerezov, $\mathrm{v}$ pomoč pa so bili tudi digitalni ortofoto posnetki (DOF), narejeni vzporedno z lidarskim snemanjem.

Za obe snemanji (2007 in 2010) smo točke, ki so bile klasificirane kot tla, pretvorili v rastre $\mathrm{z}$ ločljivostjo $0,1 \mathrm{~m} \times 0,1 \mathrm{~m}$. Nato smo izvedli primerjavo rastrov, in sicer smo od rastra talnih točk iz leta 2007 odšteli raster talnih točk iz leta 2010 ter dobili raster razlik. Ker je vertikalna natančnost lidarskega snemanja približno $10 \mathrm{~cm}$, so območja razlik pod pragom natančnosti izvzeta iz analize. Upoštevali smo tako negativne vrednosti razlik med letoma 2007 in 2010 kot pozitivne vrednosti razlik. Negativne vrednosti predstavljajo razlike med letoma 2007 in 2010, kjer naj ni prišlo do nakopičenja gradiva, pozitivne vrednosti pa razlike, kjer naj bi prišlo do odnašanja gradiva.

Glede uporabnosti letalskega lidarja za analize klifov je bilo v tujini narejenih nekaj raziskav (npr. Earlie in sod., 2013; Collins, Stock, 2012; Young in sod., 2010). Ključna je dilema, ali so za preučevanje sprememb na klifih dovolj uporabni zgolj podatki letalskega lidarja ali je le-te nujno potrebno kombinirati s podatki terestričnega lidarja. Raziskave so pokazale, da so podatki letalskega lidarja, če je gostota točk dovolj velika, točke pa pravilno klasificirane in interpretirane, primerni za analizo kratkoročnih sprememb na klifih, vendar pa imata tako terestrični kot letalski lidar vsak svoje prednosti in slabosti pri interpretaciji podatkov in karakterizaciji sprememb (Earlie in sod., 2013; Collins, Stock, 2012; Young in sod., 2010). Lidarsko snemanje iz zraka pokrije večje območje ter zajame vrh klifa in njegovo pobočje. Uporabno je za oceno umikanja vrha klifa in analizo 
stabilnosti plazovitih območij, ki se raztezajo dlje od čela klifa. Lidarsko snemanje s površja poda večjo zgoščenost točk, je natančnejše in bolj mobilno ter primerno za topografijo specifičnih plazov in sprememb na manj obsežnih območjih. Zazna tudi morske jame in vdolbine, ki so pomembne pri analizi zemeljskih usadov/plazov, medtem ko lidarsko snemanje iz zraka te večinoma spregleda. Kombiniranje obeh lidarjev omogoča popolno pokritje površja in lajša njegovo analizo (Young in sod., 2010).

\section{REZULTATI:ANALIZA, PRIMERJAVA IN INTERPRETACIJA PODATKOV}

Analize in primerjave podatkov smo se lotili v treh fazah. V prvi fazi je potekala identifikacija razlik na podlagi rastra razlik med letoma 2007 in 2010 . V drugi fazi smo s pomočjo digitalnih ortofoto posnetkov, ki so bili narejeni v času lidarskega snemanja, terenskega ogleda in fotografij, posnetih na terenu, skušali ugotovljene spremembe identificirati. V tretji fazi smo identificirane spremembe poskusili tipizirati in obrazložiti. Analiza klifa je potekala po odsekih, ki jih prikazuje slika 3: klif smo razdelili v šest enako dolgih odsekov, ki so oštevilčeni od zahoda proti vzhodu.

Slika 3: Klif med Fieso in Pacugom z odseki, po katerih je potekala analiza sprememb med letoma 2007 in 2010.

Figure 3: Cliff between Fiesa and Pacug (divided into sectors for the purpose of 2007-2010 change analysis).

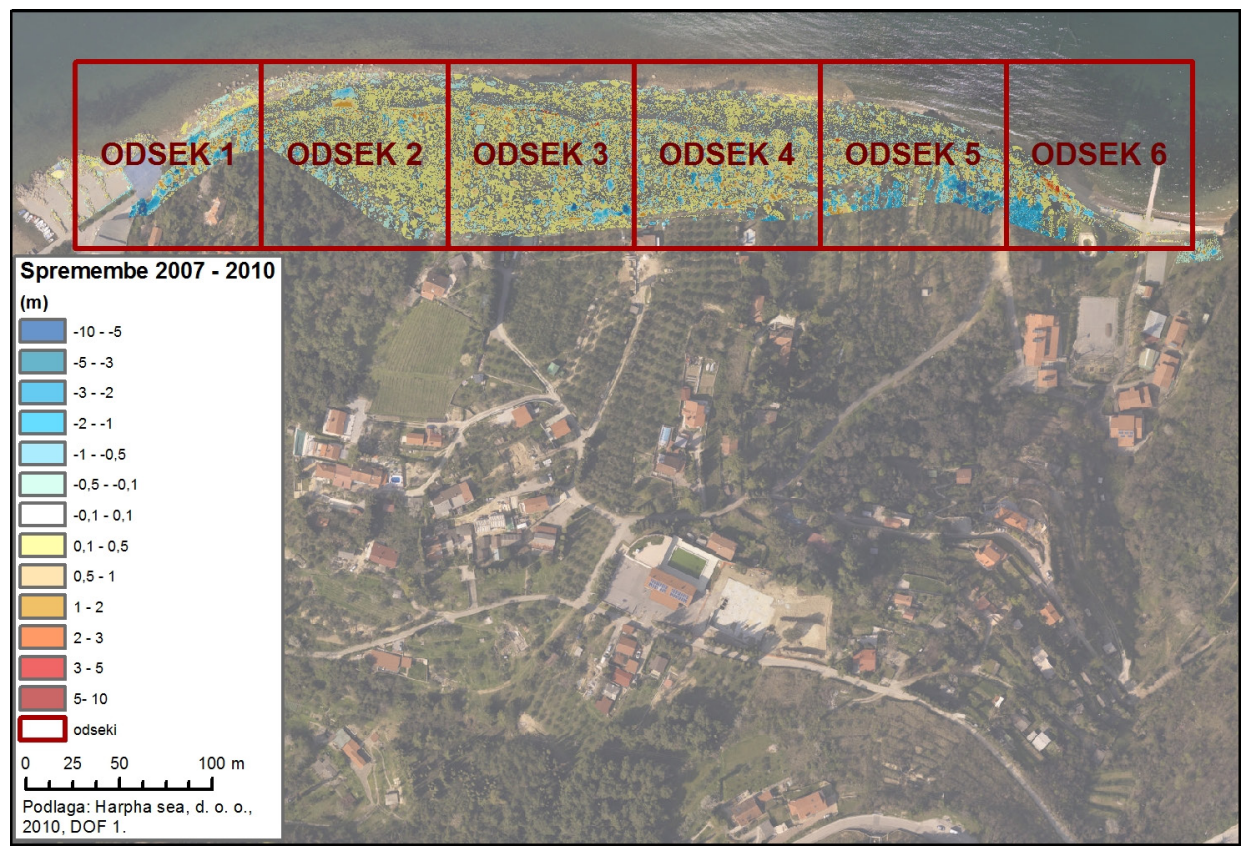




\section{I Identifikacija sprememb na rastru razlik med letoma 2007 in 2010}

Na podlagi rastra razlik med letoma 2007 in 2010 so bila identificirana območja, kjer se pojavljajo razlike v stanju med letoma 2007 in 2010. Dejansko gre za dva tipa razlik:

- ali je bila nadmorska višina tal na neki točki klifa leta 2010 višja kot 2007, kar bi posledično pomenilo, da se je gradivo tam kopičilo;

- ali pa je bila nadmorska višina tal na neki točki leta 2010 nižja kot 2007, kar bi posledično pomenilo, da je bilo gradivo od tam erodirano.

Slika 3 prikazuje raster razlik med letoma 2007 in 2010 (2010 smo odšteli od 2007). Barvna paleta od rdečih do rumenih barv označuje območja, kjer je bilo gradivo erodirano - v legendi so označena s pozitivnimi vrednostmi. Višja vrednost pomeni, da je bilo več gradiva zaradi različnih dejavnikov erodiranega. Barvna paleta od svetlo do temno modrih barv predstavlja območja, kjer se je gradivo nakopičilo (v legendi so označena z negativnimi vrednostmi). Višja negativna vrednost pomeni, da se je na tistem območju nakopičilo več gradiva. Vrednosti med $-0,1$ in 0,1 so prosojne, saj so pod pragom natančnosti lidarskega snemanja, zato jih v raziskavi ne moremo upoštevati.

\subsection{Identifikacija sprememb po odsekih}

Slika 4: Spremembe na odseku 1.

Figure 4: Changes on sector 1.

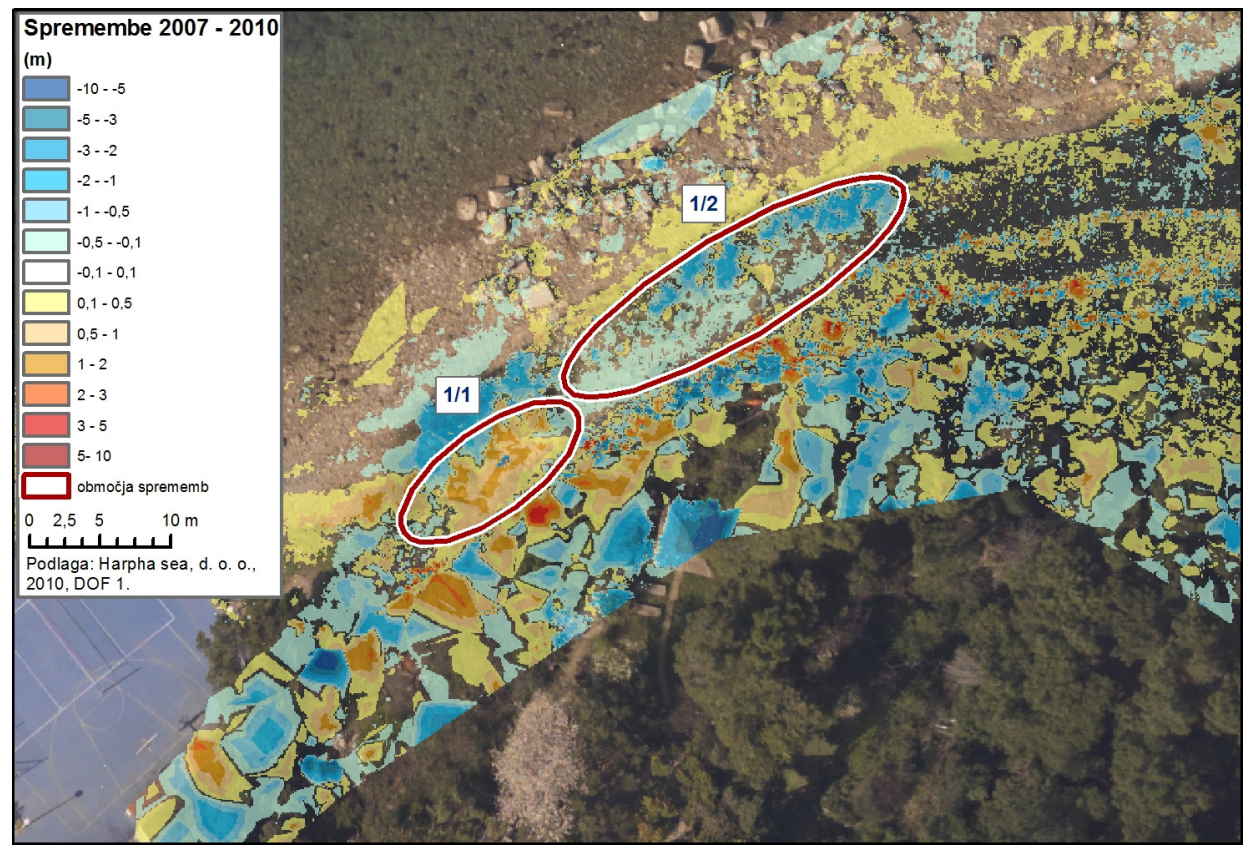


Spremembe so bile identificirane na robnem delu klifa, vrhu klifa, steni klifa in na abrazijski polici. Izrazito je območje erodiranega gradiva, na sliki 4 je označeno kot 1/1. Iz primerjave ortofoto posnetkov iz let 2007 in 2010 je jasno razvidno, da je bilo drevo na robu klifa, ki je preprečevalo odnašanje gradiva z zgornjega roba klifa, posekano, zato je prišlo do intenzivnejšega odnašanja gradiva in posledično tudi akumuliranja na abrazijski ravnici. Pri območju 1/2, ki se ravno tako nahaja na abrazijski polici, kaže, da se je gradivo s stene klifa odkrušilo in padlo na abrazijsko polico. Na tem območju je v preučevanem obdobju nastala pot, zaradi katere so posekali velik del vegetacije na zgornjem robu klifa. Ta je pred tem preprečevala odnašanje gradiva z zgornjega roba klifa. Gradivo se sedaj intenzivneje kopiči na abrazijski polici.

Slika 5: Spremembe na odseku 2.

Figure 5: Changes on sector 2.

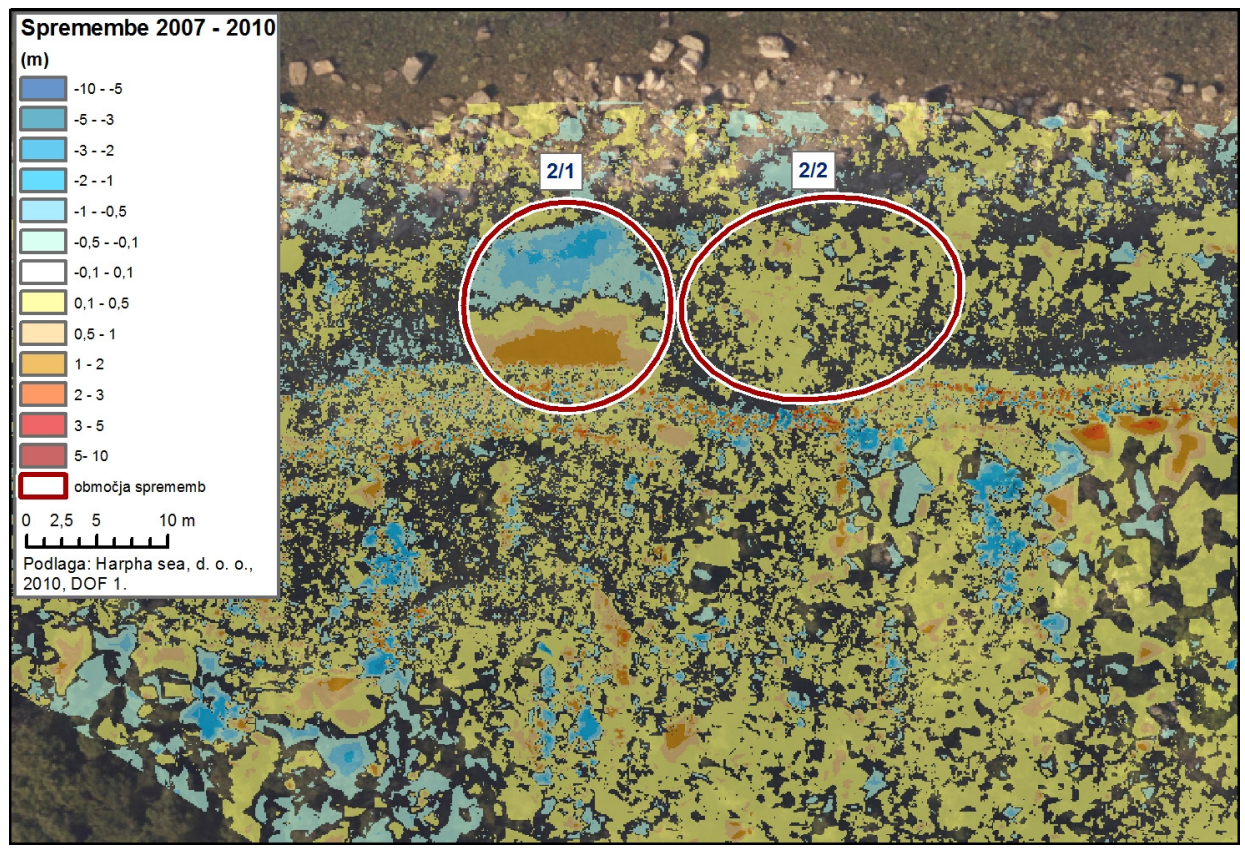

Zanimivo je območje 2/1 (slika 5), saj je nižji del v izrazito modrih barvah, višji pa v rdeče-rumenih. S pomočjo fotografij lahko ugotovimo, da na steni klifa manjka velik del kompaktnejše turbiditne plasti. Skala, ki se je odlomila, se je odkotalila po klifu do abrazijske ravnice ter s seboj odnesla tudi drobnejše gradivo.

Za območje $2 / 2$ je iz ortofoto posnetkov opaziti, da je na vrhu abrazijske police izginilo nizko rastje, ki je preprečevalo intenzivnejše odnašanje gradiva v morje. 
Slika 6: Spremembe na odseku 3.

Figure 6: Changes on sector 3.

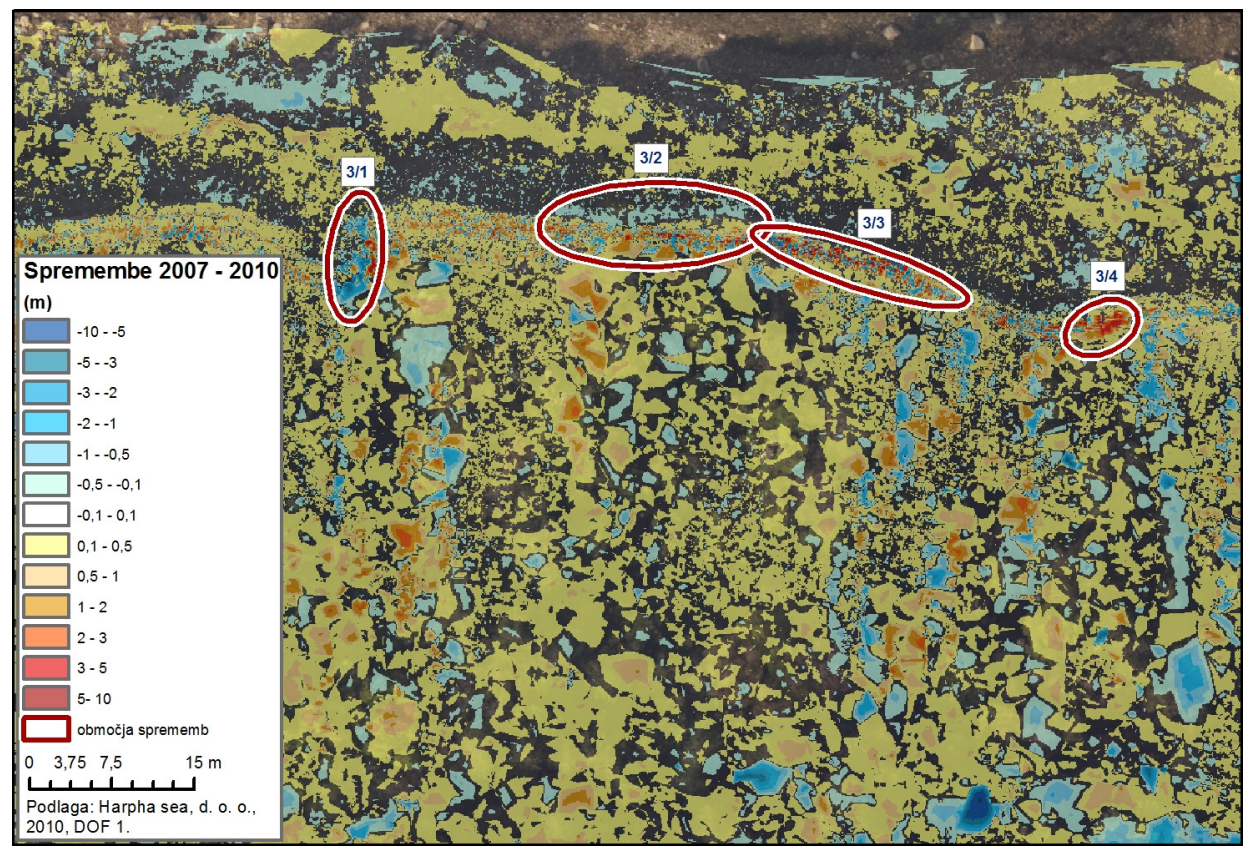

Območje 3/1 na sliki 6 je izrazito modro obarvano, iz česar sklepamo, da se je gradivo tam kopičilo. Iz fotografij je mogoče razbrati, da nad njim manjka del turbiditne plasti, ki je s seboj odnesla tudi drobnejše gradivo, ki se je na območju 3/1 ustavilo in nakopičilo. Na območju 3/2 je opaziti območje odnašanja gradiva na steni klifa in območje odlaganja gradiva na abrazijski ravnici. Pri območju 3/3 gre za prepletanje krušenja in odnašanja drobnega gradiva ter njegovega nalaganja. Za območje 3/4 je mogoče iz ortofoto posnetkov jasno videti, da gre za podor kamnine in oblikovanje melišča na abrazijski polici. Tudi tu se je del turbiditne plasti odlomil ter s seboj odnesel drobnejšs gradivo, skupaj z grmičevjem.

Na območju 4/1 na sliki 7 gre za odnašanje drobnejšega gradiva in njegovo odlaganje na abrazijski ravnici. $\mathrm{Na}$ ortofoto posnetkih je razvidno, da gre za neporaščen del klifa, kjer ni opaziti večjih odlomov. Na območju 4/2 ortofoto posnetki prikazujejo povečanje vegetacije. Ker vegetacija na zgornjem robu klifa preprečuje odnašanje gradiva in posledično njegovo odlaganje nižje, je ob vznožju klifa območje izrazitega odnašanja gradiva zaradi delovanja morja. Pri območju 4/3 imamo ponovno opraviti z odlomom večje turbiditne skale, ki je pri svojem polzenju odnesla s seboj na abrazijsko polico tudi drobnejše gradivo. Za območji 4/4 in 4/6, na katerih naj bi se gradivo nakopičilo, lahko iz ortofoto posnetkov razberemo, da sta poraščeni z nizko vegetacijo (grmičevjem). Ker grmičevje višje erodirano gradivo zadržuje, se je v obravnavanem obdobju tu nakopičilo. Območji 
Slika 7: Spremembe na odseku 4.

Figure 7: Changes on sector 4.

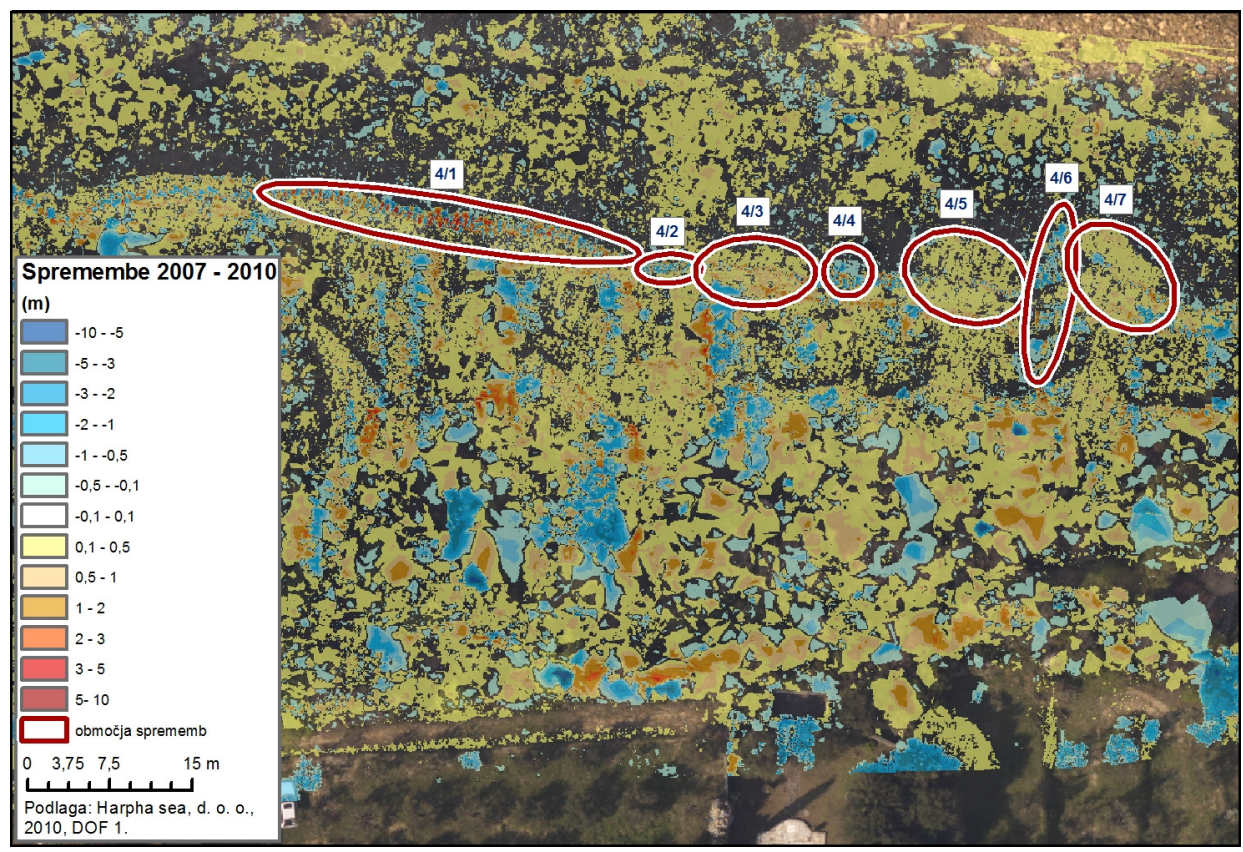

$4 / 5$ in 4/7, kjer naj bi prišlo do odnašanja gradiva, na ortofoto posnetkih prepoznamo kot aktivna melišča, iz katerih gradivo odnaša.

Pri območju 5/1 na sliki 8 gre ponovno za odlom večje skale, ki je s seboj odnesla drobnejše gradivo.

Na območju 5/2 prihaja do prepleta odnašanja in nalaganja drobnejšega gradiva. Stena klifa je neporaščena, vznožje klifa pa je neaktivno melišče, ki je že poraščeno s travami in grmičevjem. V nadaljevanju abrazijske police so skale različnih velikosti, ki so podvržene morski abraziji, kar je na karti označeno kot območje odnašanja gradiva.

Na odseku 6 (slika 9) imamo opraviti z izrazitim območjem odnašanja gradiva (6/1) iz spodnjega dela klifa zaradi delovanja morja. Na tem delu klifa je abrazijska polica zelo ozka, zato morje intenzivno spodkopava vznožje klifa.

Slika 8 (na naslednji strani zgoraj): Spremembe na odseku 5.

Figure 8 (opposite, top): Changes on sector 5.

Slika 9 (na naslednji strani spodaj): Spremembe na odseku 6.

Figure 9 (opposite, bottom): Changes on sector 6. 

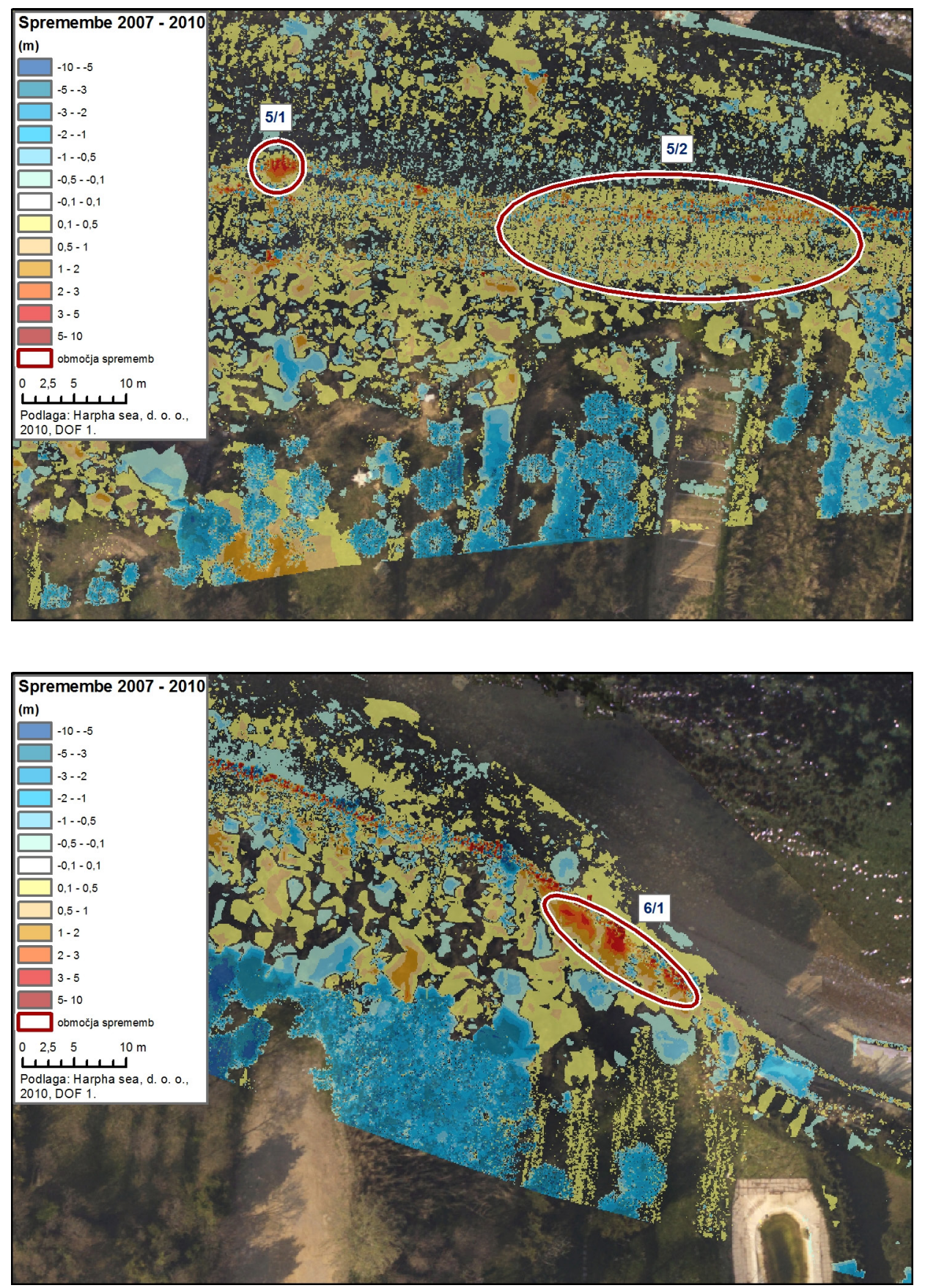


\subsection{Tipizacija sprememb}

Spremembe, ki smo jih sprva zaznali na rastru razlik med letoma 2007 in 2010 (skupno jih je bilo 18) ter jih nato identificirali in pojasnili na podlagi digitalnih ortofoto posnetkov, terenskega ogleda in fotografij, smo tipizirali na podlagi delov klifa, kjer se pojavljajo. To so:

- spremembe na abrazijski ravnici,

- spremembe na steni klifa in abrazijski ravnici ter

- spremembe na zgornjem robu in steni klifa ter abrazijski polici.

Izmed sprememb na steni klifa in abrazijski polici smo posebej izdvojili še tiste spremembe, ki jih je povzročil odlom turbiditne plasti. Največ sprememb se je zgodilo na steni klifa in abrazijski polici: 13 od skupno 18. Pet izmed teh je povzročil odlom turbiditne plasti oziroma skale, ki je spolzela na abrazijsko polico ter s seboj odnesla tudi drobnejše gradivo s pobočja. Pri ostalih 12 spremembah tega tipa je šlo zgolj za odnašanje drobnejšega gradiva. Tri spremembe so vključevale zgornji rob klifa, steno in abrazijsko ravnico, dve pa samo abrazijsko ravnico. Pri večjem delu omenjenih sprememb je bil osnovni razlog v spremembi rastja (npr. odstranitvi rastja, ki je zadrževalo polzenje drobnejšega gradiva).

Največ sprememb se je zgodilo na odsekih 3 in 4, za katera bi lahko rekli, da sta osrednja odseka klifa. Nahajata se na sredini klifa, spremembe pa pričajo o tem, da je klif na tem delu tudi najaktivnejši. Največ sprememb na odsekih 3 in 4 se je zgodilo na steni in abrazijski polici (skupaj 10), od tega je bil povzročitelj treh odlom turbiditne plasti.

Izmed osemnajstih identificiranih sprememb smo na rastru razlik, na digitalnih ortofoto posnetkih, terenu in fotografijah $\mathrm{s}$ terena uspešno identificirali vse spremembe. Iz tega izhaja, da lahko s takšno metodo dela zgolj s primerjavo dveh nizov podatkov lidarskega snemanja pravilno določimo razmeroma velik del sprememb na klifu. $Z$ nadaljnjo analizo digitalnih ortofoto posnetkov in terenskim ogledom lahko identificirane spremembe na rastru razlik potrdimo ali ovržemo. Pojavlja se vprašanje, kolikšen delež vseh kratkoročnih sprememb na klifu predstavljajo spremembe, ki smo jih uspešno identificirali. To bi verjetno najbolj zanesljivo ugotovili, če bi klif posneli še s terestričnim lidarjem, saj bi tako prišle do izraza tudi manjše, letalskemu lidarju skrite spremembe. Dejstvo je, da je zaradi pogoste goste poraščenosti zgornjega dela klifa spremembe na tem delu težje identificirati, istočasno pa je bilo med raziskavo ugotovljeno, da so bolj poraščeni deli klifa manj podvrženi spremembam, saj jih vegetacija pred njimi ščiti.

Na zgornjem robu klifa gradivo zadržuje nizko, gosto rastje. Visoko rastje zadrži manj gradiva kot srednje in nizko rastje. Na neporaščenih zgornjih robovih klifa je krušenje in polzenje gradiva veliko intenzivnejše. Ob večjih padavinskih dogodkih je krušenje in odnašanje gradiva najizrazitejše in običajno takrat prihaja do največjih sprememb na klifih (Furlani in sod., 2011).

Stena klifa je lahko gola, vsebuje trdnejše turbiditne plasti ali pa je poraščena. Če je stena klifa gosto poraščena, vegetacija zadrži gradivo. Če je na steni prisotna tudi trdnejša plast kamnine (turbidit), je območje dokaj neaktivno in polica iz turbidita zadržuje 
Preglednica 1: Statistika identificiranih sprememb po odsekih in tipih.

Table 1: Statistics of identified changes (respecting sectors and types).

\begin{tabular}{|c|c|c|c|c|c|c|c|}
\hline Tipremembe & Odsek 1 & Odsek 2 & Odsek 3 & Odsek 4 & Odsek 5 & Odsek 6 & $\begin{array}{c}\text { Skupno } \\
\text { število } \\
\text { sprememb }\end{array}$ \\
\hline Abrazijska polica & & $2 / 2$ & & & & $6 / 1$ & \\
\hline $\begin{array}{l}\text { Abrazijska polica } \\
\text { (skupaj) }\end{array}$ & & 1 & & & & 1 & 2 \\
\hline $\begin{array}{l}\text { Stena in abrazijska } \\
\text { polica }\end{array}$ & & & $3 / 23 / 3$ & $\begin{array}{c}4 / 14 / 4 \\
4 / 54 / 6 \\
4 / 7 \\
\end{array}$ & $5 / 2$ & & \\
\hline $\begin{array}{l}\text { Odlomi turbiditne } \\
\text { plasti }\end{array}$ & & $2 / 1$ & $3 / 13 / 4$ & $4 / 3$ & $5 / 1$ & & \\
\hline $\begin{array}{l}\text { Stena in abrazijska } \\
\text { polica (skupaj) }\end{array}$ & & 1 & 4 & 6 & 2 & & 13 \\
\hline $\begin{array}{l}\text { Zgornji rob, stena } \\
\text { klifa in abrazijska } \\
\text { polica }\end{array}$ & $1 / 11 / 2$ & & & $4 / 2$ & & & \\
\hline $\begin{array}{l}\text { Zgornji rob, stena } \\
\text { klifa in abrazijska } \\
\text { polica (skupaj) }\end{array}$ & 2 & & & 1 & & & 3 \\
\hline $\begin{array}{l}\text { Skupno število } \\
\text { sprememb }\end{array}$ & 2 & 2 & 4 & 7 & 2 & 1 & 18 \\
\hline
\end{tabular}

pobočno gradivo. Ko pa zaradi različnih zunanjih dejavnikov pride do odloma večje turbiditne skale, ta pod seboj sproži serijo podorov in odnašanje erodiranega gradiva proti spodnjemu delu klifa in abrazijski polici. Če v klifu ni te trdnejše plasti, pa gravitacija, razpokanost in zunanji vplivi pospešeno odnašajo gradivo s stene.

Abrazijska polica pod obravnavanim klifom je zelo raznolika. Stik med steno klifa in abrazijsko polico večinoma predstavljajo melišča. Nekatera izmed njih so popolnoma neaktivna in poraščena, $\mathrm{v}$ večini primerov s traviščem ali nizkim grmičevjem. V spodnjem delu melišč in na abrazijski polici so tudi velike turbiditne skale, ki so se odlomile s stene klifa. Prisotno je gradivo različnih velikosti, tj. od zelo drobnega peska do razmeroma velikih skal. Kjer so prisotne velike skale, je vpliv morja in odnašanje gradiva običajno manjše. Kjer so manjši kamni in droben pesek, pa je delovanje morja zelo veliko.

\section{SKLEP}

Poskus določanja kratkoročnih sprememb na flišnem klifu med Fieso in Pacugom, s pomočjo dveh nizov podatkov letalskih lidarskih snemanj v razmiku treh let, se je pokazal kot zelo uporaben. Spremembe, ki smo jih identificirali pri primerjavi lidarskih podatkov, smo uspešno identificirali in razložili tudi s pomočjo ortofoto posnetkov ter na terenu oziroma s pomočjo fotografij s terena. Največji delež razlik se je zgodil na steni klifa in 
Slika 10: Klif med Fieso in Pacugom. Na fotografiji je viden: zgornji, poraščen rob klifa; trdnejša turbiditna plast v zgornjem delu stene klifa; večinoma s travo poraščeno melišče ob vznožju klifa in z večjimi turbiditnimi skalami posuta abrazijska ravnica (foto: P. Prelc, 2015). Figure 10: The cliff between Fiesa and Pacug. On this photography it is possibile to see the upper edge of the cliff, covered with vegetation; the turbidite layer on the upper part of cliff wall; the scree mostly covered with grass and the abrasion platforms with bigger turbidite rocks (photo: P. Prelc, 2015).

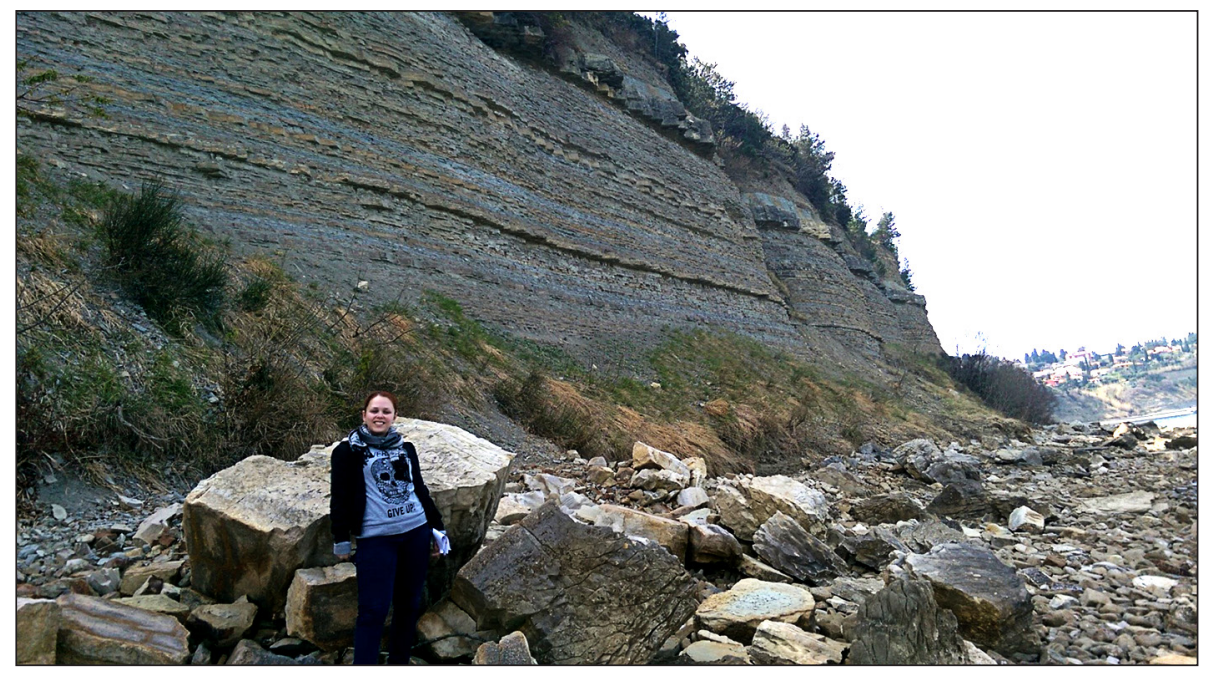

abrazijski polici ter na osrednjem delu klifa, iz česar sklepamo, da je to najaktivnejši del klifa. Ostaja pa odprto vprašanje, koliko sprememb je ostalo prikritih. Dejstvo, da je bila slovenska obala že trikrat posneta z lidarjem, je vsekakor velika prednost, ki odpira veliko novih možnosti raziskav.

Pokazala se je tudi pričakovana težava uporabe lidarskih posnetkov. Na območjih, kjer je vegetacija zelo gosta, laserski žarki niso dosegli tal, zato so lahko v takih primerih podatki nezanesljivi, primerjava pa otežena. Ta problem je bil posebej prisoten na zgornjem robu klifa. Za zgornji rob klifa je bilo ugotovljeno, da je prenos erodiranega gradiva precej odvisen od vegetacije na njem, saj srednje do nizko rastje zaradi svoje goste zarasti zadrži veliko gradiva. V primeru visokega rastja ali neporaščenosti pa je krušenje in odnašanje gradiva večje. Stena klifa je lahko poraščena ali gola, aktivnost je na goli steni bistveno večja.

Na steni preučevanega klifa zasluži posebno pozornost plast odpornejšega apnenčevega turbidita, ki pogosto izrazito »štrli« iz stene. Redno prihaja tudi do lomljenja večjih skal turbidita, ki s seboj odnašajo tudi drobnejše gradivo na spodnje dele klifa in abrazijsko ravnico. Abrazijska polica je lahko poraščena; kjer je vpliv morja večji, je tudi neporaščena. Gradivo, nakopičeno na njej, je lahko drobnejše ali pa gre za večje skale, ki v določeni meri varujejo abrazijsko ravnico in spodnji del klifa pred vplivom morja. 
Omeniti velja, da smo se pri primerjavi stanja klifa med Fieso in Pacugom omejili na točke snemanja, ki predstavljajo tla, nismo pa upoštevali in primerjali točk, ki predstavljajo vegetacijo, kar bi nam najverjetneje še dodatno razkrilo in pojasnilo nekatere spremembe na klifu. Razlog je v tem, ker snemanje ni bilo izvedeno v istih letnih časih, zato analiza ne bi bila smiselna (leta 2007 je bilo snemanje izvedeno novembra, ko je listopadna vegetacija večinoma brez listja; leta 2010 pa aprila, ko se olistanje že začenja). Raziskava je pokazala, da je uporaba letalskih lidarskih posnetkov kljub določenim pomanjkljivostim lahko zelo uporaben pripomoček pri preučevanju kratkoročnih sprememb na klifih.

\section{Literatura in viri}

Collins, D. B., Stock G. M., 2012. Lidar-Based Rock-Fall Hazard Characterization of Cliffs. GeoCongress 2012: State of the Art and Practice in Geotechnical Engineering. American Society of Civil Engineers, str. 3021-3030. DOI: 10.1061/9780784412121.309.

Earlie, C., Masselink G., Russell P., Shail, R., 2013. Sensitivity analysis of the methodology for quantifying cliff erosion using airborne LiDAR - examples from Cornwall, UK. Journal of Coastal Research Special Issue, 65, str. 470-475. DOI: 10.2112/SI65-080.1.

Furlani, S., 2007. Evoluzione della falesia di Punta Grossa. Borgolauro, nuove pagine muggesane, rivista semestrale di storia lettere ed arti della Fameia muiesana, 28, 52, str. 9-16.

Furlani, S., Devoto S., Biolchi B., Cucchi F., 2011. Spremembe obalnega klifa: Študija primera Debelega Rtiča (JZ Slovenija). Annales, 21, 1, str. 773-786.

Furlani, S., Biolchi, S., Cucchi, F., Antonioli, F., Busetti, M., Melis, R., 2011. Tectonic effects on Late Holocene sea level changes in the Gulf of Trieste (NE Adriatic Sea, Italy). Quaternary International 232/1-2, str. 144-157. DOI: 10.1016/j. quaint.2010.06.012.

Gams, I., 1970. Severna obala Strunjanskega polotoka. Proteus, 33, str. 56-62.

Harpha sea, d. o. o. Koper, 2007a. Digitalni ortofoto posnetki, posneti med lidarskim snemanjem, območje Občine Piran.

Harpha sea, d. o. o. Koper, 2007b. Podatki laserskega snemanja z lidarjem, območje Občine Piran.

Harpha sea, d. o. o. Koper, 2010a. Digitalni ortofoto posnetki, posneti med lidarskim snemanjem, območje Občine Piran.

Harpha sea, d. o. o. Koper, 2010b. Podatki laserskega snemanja z lidarjem, območje Občine Piran.

Kladnik, D., 2001. Geografija. Tržič, Učila International, 682 str.

Orožen Adamič, M., 1990. Podvodni relief Tržaškega zaliva in varovanje naravne dediščine. V: Primorje. Zbornik 15. zborovanja slovenskih geografov. Ljubljana, Zveza geografskih društev Slovenije, str. 21-27.

Peckmann, J., 1995. Das Flysch-Becken von Piran in Istrien - mit geologischer Kartierung 1:25000. Diplomarbeit. Göttingen, Institut für Geologie und Paläontologie der Georg-August-Universität Göttingen. 
Placer, L., 2008. Principles of the tectonic subdivision of Slovenia. Geologija, 51/2, str. 205-217.

Radinja, D., 1973. Prispevek k spoznavanju recentnega abrazijskega reliefa na primeru strunjanske obale. Mednarodni mladinski raziskovalni tabori 1971-1972. Ljubljana, Republiški koordinacijski odbor gibanja »znanost mladini«, str. 72-94.

Schwartz, L. M., 2005. Encyclopedia of coastal science. Dordrecht, Springer, 1086 str.

Šegina, E., 2012. Oblike in procesi na flišnih obalnih stenah. Diplomsko delo. Koper, Univerza na Primorskem, Fakulteta za humanistične študije, 135 str.

Šegina, E., Komac, B., Zorn M., 2012. Vplivni dejavniki umikanja flišnih klifov na slovenski obali. Acta geographica Slovenica, 52, 2, str. 303-334. DOI: 103986/AGS52202.

Vlada RS. 2004. Zakon o ohranjanju narave. Uradni list RS, 96. Ljubljana.

Young, P. A., Olsen, M. J., Driscoll, N., Flick, R. E., Gutierrez, R., Guza, R. T., Johnstone, E. Kuester, F., 2010. Comparison of Airborne and Terrestrial LIDAR Estimates of Seacliff Erosion in Southern California. Photogrammetric Engineering \& Remote Sensing, 76, 4, str. 421-427.

Zorn, M., 2008. Erozijski procesi v slovenski Istri. Ljubljana, Založba ZRC, 423 str.

Žumer, J., 1990. Recentni razvoj klifov na obalah istrske Slovenije. 5. znanstveno posvetovanje geomorfologov Jugoslavije. Ljubljana, ZRC SAZU, str. 143-147.

\section{DETERMINING SHORT-TERM CHANGES ON CLIFF BETWEEN FIESA AND PACUG WITH AIRBORN LIDAR DATA}

\section{Summary}

On Slovenian coast, flysch cliffs represent $60 \%$ of the coastline (Orožen Adamič, 1990). Despite such strong representation, there are relatively few surveys of short-term changes on flysch cliffs on Slovenian coast. The paper deals with what is, for Slovenian conditions, considered an experimental attempt of determining short-term changes on flysch cliff using airborne lidar data. The area under investigation was the cliff between Fiesa and Pacug because it is still relatively natural and intact, with very little human intervention on it.

For this part of the coast, between Fiesa and Pacug, there are available data from two lidar scannings - from 2007 and 2010. By comparison we wanted to determine whether by using two sets of lidar data scanned at times three years apart, we can determine any changes on the cliff, whether the data is accurate enough given the magnitude of the cliff changes, and finally what methodological approaches are most appropriate.

The study used raw lidar data in the form of point cloud. Our study focused on the changing of the cliff's ground, so we classified the point cloud into two classes: ground and other points. The determination of ground points on the slopes of the cliff is a complex process, due to the intermingling of rocks and vegetation, changing of the slope and forms, therefore it needed much attention. Classification was done mostly manually through narrow cross sections, with the support of digital orthophoto maps that were produced in parallel with lidar scanning. 
The analysis started with the creation of two rasters representing ground, for the years 2007 and 2010. The comparison of rasters was made by subtracting ground raster for 2010 from the ground raster for 2007, thus getting the raster of differences. Since the vertical accuracy of lidar scanning is about $10 \mathrm{~cm}$, the areas of differences below the threshold accuracy were excluded from the analysis. We took into account both the negative value of the differences between 2007 and 2010 and the positive value of the differences. Negative values represent the areas on which the material was accumulated, while positive values indicate areas where the material was eroded.

The comparison of data and the analysis was done in three phases. In the first phase we identified the differences based on raster of differences between 2007 and 2010. In the second phase we identified and explained the changes found, with the help of digital orthophotos, which were made during the lidar scanning, fieldwork and photos recorded on the field. In the third phase, we typified the identified changes. For better understanding, the cliff was divided into six sections of equal length.

In Phase 1 we located 18 changes in the raster of differences and in Phase 2 we successfully identified them on digital orthophotos, on fieldwork and on photos from the field. In Phase 3 changes have been typified in three types: changes on the upper edge of the cliff, the wall and the abrasion platform; changes on the wall and abrasion platform; and changes on abrasion platform. The majority of changes occurred on the wall and abrasion platform (13 of 18). 5 of them were caused by the breaking of turbidite layer. 3 changes occurred on the upper edge of the cliff, the wall and the abrasion platform and 2 changes occurred only on abrasion platform. The last two groups of changes were mainly caused by vegetation changes.

The identified change in raster of differences can be confirmed or discarded by further analysis of digital orthophotos and field research. This raises the question of what proportion of all short-term changes on the cliff corresponds to the changes that we have successfully identified. The most reliable way to determine this would be by scanning the cliff with terrestrial lidar, as this would show even smaller changes, hidden to airborn lidar. Due to the dense vegetation in the upper part of the cliff, the changes there were harder to identify, and at the same time these parts of the cliff were less subject to changes, since they were protected by dense vegetation.

At the upper edge of the cliff, the material is retained by low, dense vegetation. High vegetation retains less material than medium and low vegetation. On the denuded upper edge of the cliff, the crumbling and slipping of material is more pronounced. During heavy precipitation events, the crumbling and the removal of material is larger and that is when major changes in the cliffs occur (Furlani et al., 2011a).

If the vegetation on the cliff wall is dense, the vegetation retains material. If the wall contains the strong layer of rocks (called turbidites), the area is relatively inactive and the shelf made of turbidite retains material. When, due to various external factors, larger turbidite rocks start to break, this triggers a series of rockfalls and removal of eroded material towards the bottom of the cliff and the abrasion platform. If the cliff does not contain this strong layer, then gravitation, cracks and external influences erode the material from the wall faster. 
The contact between the cliff wall and the abrasion platform on some parts is covered by vegetation, which means that it is inactive. On abrasion platform, turbidite rocks of various sizes that have broken off from the wall of the cliff can be found. In the areas of large rocks, the influence of the sea is smaller, as the removal of material is smaller. In the area of smaller stones and fine sands, the effect of the tides and the sea is larger.

The experiment of determining the short-term changes in the flysch cliff with the help of two airborne lidar scannings with an interval of three years has proved to be very useful. Most of the changes occurred on the wall of the cliff and on the abrasion platform, on the central part of the cliff. We can conclude that this is the most active part of the cliff between Fiesa and Pacug. The study showed that the airborne lidar scanning, despite its well-known deficiency in the scanning of cliffs, can be a very useful tool in the study of short-term changes on the cliffs on Slovenian coast and elsewhere.

(Translated by the authors) 